\title{
Two new species of Acanthocotyle Monticelli, 1888 (Monogenea: Acanthocotylidae), parasites of two deep-sea skates (Elasmobranchii: Rajiformes) in the South-East Pacific
}

\author{
Luis A. Ñacari ${ }^{1,2}$, Fabiola A. Sepúlveda ${ }^{3}$, Ruben Escribano ${ }^{2}$ and Marcelo E. Oliva ${ }^{2,3^{*}}$ (1)
}

\begin{abstract}
Background: Parasites of deep-sea fishes from the South-East Pacific (SPO) are poorly known. Of c.1030 species of fish found in this area, 100-150 inhabit the deep-sea (deeper than 200 m). Only six articles concerning metazoan parasites of fish from deep-waters of SOP are known, and nine monogenean species have been reported. Currently, ten species are known in Acanthocotyle Monticelli, 1888 (Monogenea) and when stated, all of them are found in shallow waters (10-100 m). Acanthocotyle gurgesiella Ñacari, Sepulveda, Escribano \& Oliva, 2018 is the only known species parasitizing deep-sea skates $(350-450 \mathrm{~m})$ in the SPO. The aim of this study was the description of two new species of Acanthocotyle from two Rajiformes.

Methods: In September 2017, we examined specimens of two species of deep-sea skates (Rajiformes), Amblyraja frerichsi (Krefft) and Bathyraja peruana McEachran \& Myyake, caught at c.1500 m depth off Tocopilla, northern Chile, as a by-catch of the Patagonian tooth fish Dissostichus eleginoides Smitt fishery. Specimens of Acanthocotyle were collected from the skin of the skates. Morphometric (including multivariate analysis of proportional measurements, standardized by total length), morphological and molecular analyses (LSU rRNA and cox1 genes) were performed in order to identify the collected specimens.

Results: The three approaches used in this study strongly suggest the presence of two new species in the genus Acanthocotyle: Acanthocotyle imo n. sp. and Acanthocotyle atacamensis n. sp. parasitizing the skin of the thickbody skate Amblyraja frerichsi and the Peruvian skate Bathyraja peruana, respectively. The main morphological differences from the closely related species Acanthocotyle verrilli Goto, 1899 include the number of radial rows of sclerites, the non-discrete vitelline follicles and the number of testes.
\end{abstract}

Conclusions: The two species of monogeneans described here are the only recorded parasites from their respective host species in the SPO. Assessing host specificity for members of Acanthocotyle requires clarifying the systematics of Rajiformes.

Keywords: Monogenea, Acanthocotyle imo n. sp., Acanthocotyle atacamensis n. sp., Amblyraja frerichsi, Bathyraja peruana, South-East Pacific Ocean, Deep-sea parasites, Skates

\footnotetext{
*Correspondence: marcelo.oliva@uantof.cl

${ }^{3}$ Instituto Ciencias Naturales Alexander von Humboldt, Universidad de

Antofagasta, Antofagasta, Chile

Full list of author information is available at the end of the article
} 


\section{Background}

The deep-sea is one of the most fascinating ecosystems on earth [1], covering more than two-thirds of the world's surface with an average depth of $3800 \mathrm{~m}$ and a maximum depth of $c .11,000 \mathrm{~m}$ in Mariana Trench [2], but knowledge of biodiversity in this environment is still scarce [3]. Knowledge of biodiversity in the Atacama Trench, closely associated to the high productive Humboldt Current Marine Ecosystem is limited; the assemblage of deepsea nematodes, the community of soft-shelled benthic foraminiferans and the presence of some amphipods have been described [4-6]. Surprisingly, the Atacama Trench is characterized by very high concentrations of nutritionally-rich organic matter up to depths of $7800 \mathrm{~m}$, displaying characteristics typical of eutrophic systems [4]. The near-total lack of research on the parasites of deep-sea fish in the Atacama Trench represents an important gap in our knowledge of the biodiversity and structure of deep-sea communities in this trench [7] because hostparasite interactions may shape components of ecological communities [8]. Studies of the diversity of parasites of deep-sea fishes in the South-East Pacific (SPO), particularly for monogeneans are limited, and to date 11 monogenean species were recorded from deep-sea fishes in the SPO $[7,9,10]$.

Acanthocotyle Monticelli, 1888 (Monopisthocotylea: Acanthocotylidae) includes parasites of the skin of skates and stingrays [11], which are considered specific parasites of Rajiformes, except for Acanthocotyle urolophi Kearn, Whittington, Chisholm \& Evans-Gowing 2016, found in Urolophus cruciatus Lacépède (Myliobatiformes) and Acanthocotyle sp. from Narcine maculata (Shaw) (Torpediniformes) [12]. Ten valid species have been described to date: Acanthocotyle lobianchi Monticelli, 1888 (type-species); A. elegans Monticelli, 1890; A. verrilli Goto, 1899; A. pacifica Bonham \& Guberlet, 1938; A. pugetensis Bonham \& Guberlet, 1938; A. williamsi Price, 1938; A. patagonica Kuznetsova, 1971; A. greeni Macdonald \& Llewellyn, 1980; A. urolophi Kearn, Whittington, Chisholm \& Evans-Gowing 2016 and $A$. gurgesiella Nacari, Sepulveda, Escribano \& Oliva, 2018. Of these, only two species, A. pacifica and A. gurgesiella were described from deep-sea skates.

A detailed morphological and molecular study revealed that monogeneans obtained from the skin of two deepsea skates Amblyraja frerichsi (Krefft) and Bathyraja peruana McEachran \& Miyake, from SPO represent new species. These are described and differentiated below.

\section{Methods}

\section{Sample collection and processing}

In September 2017, ten specimens of both species, the thickbody skate $A$. frerichsi and Peruvian skate $B$. peruana (Rajiformes) were obtained as by-catch from the local demersal long-line fishery on Patagonian tootfish Dissostichus eleginoides Smitt (Nototheniidae) in SPO (off Tocopilla, northern Chile; $22^{\circ} 16^{\prime} \mathrm{S}, 70^{\circ} 38^{\prime} \mathrm{W}-23^{\circ} 26^{\prime} \mathrm{S}$, $70^{\circ} 43^{\prime} \mathrm{W}$ ) caught at depths of $c .1500 \mathrm{~m}$. The fish were immediately frozen (at $-18{ }^{\circ} \mathrm{C}$ ) on board and transported to the laboratory for parasitological analysis. The dorsal surface was washed in tap water, and the mucus was sieved and examined for monogeneans using a dissecting microscope with transmitted light. Some monogeneans were fixed in AFA (alcohol: formalin: acetic acid; $1: 1: 8)$ or $4 \%$ neutral buffered formaldehyde and then transferred and stored in $70 \%$ ethanol for further morphological analyses (light microscopy). Selected monogeneans from each of the two hosts were transferred to $96 \%$ ethanol for DNA analyses.

Population descriptors, prevalence and mean intensity [13] were recorded for both parasite species.

\section{Morphological and statistical analyses}

Fixed specimens were stained with Gomori's trichrome and cleared with clove oil (Sigma-Aldrich, Taufkirchen, Germany), then mounted in Eukitts ${ }^{\circledR}$ (O. Kindler GmBH, Freiburg, Germany). The specimens were photographed (Leica M125 camera, Wetzlar, Germany) and measured using ImageJ [14]. Figures were made with a drawing tube. Measurements are in micrometers and are given as the range followed by the mean and the number of structures measured or counted in parentheses. The type-material was submitted to the National Museum of Natural History of the Smithsonian Institution, Washington, USA (NMNH-SI), Museo de Historia Natural, Universidad Nacional Mayor de San Marcos, Lima, Perú (MHN-UNMSM) and the Natural History Museum, London, UK (NHMUK).

To comply with the regulations set out in article 8.5 (amended version 2012) of the International Code of Zoological Nomenclatures (ICZN), details of the paper have been submitted to ZooBank. The LSID (Life Science Identifier) is urn:lsid:zoobank. org:pub:61DF198B-CF21-4B5E-B9BF-D7B80B187E49.

Principal components analysis (PCA) was performed for proportional morphometric measurements [15]. The ratios body width/total length (TL), body length (excluding posthaptor)/TL, pharynx length/TL, pharynx width/ $\mathrm{TL}$, diameter of the pseudohaptor/TL, number of sclerite rows/TL, testes maximum width/TL, germarium length/TL and germarium width/TL were used instead of the original measurements because previous results indicated a correlation between the morphological variables and the total length [16]. Subsequently, the first five main components of the PCA, explaining $90.4 \%$ of the 
variance, were used in a multivariate discriminant analysis (MDA). Statistical analyses were performed with Statistica 10.0.

\section{Molecular data and phylogenetic analyses}

Parasites were preserved in 95\% ethanol and placed individually into $1.5 \mathrm{ml}$ Eppendorf tubes for DNA extraction. The DNA of each individual was isolated following a modified protocol [17], involving treatment with sodium dodecyl sulfate, digestion with Proteinase $\mathrm{K}, \mathrm{NaCl}$ protein precipitation, and subsequent ethanol precipitation of the DNA.

For molecular analyses, regions within the nuclear $L S U$ rRNA and the mitochondrial gene cytochrome $c$ oxidase 1 ( $\operatorname{cox} 1$ ) were used. LSU rRNA was amplified by polymerase chain reaction (PCR) with the forward primer $\mathrm{C} 1\left(5^{\prime}-\right.$ ACC CGC TGA ATT TAA GCA T-3') and the reverse primer D2 (5'-TGG TCC GTG TTT CAA GAC-3') [18]; cox1 was amplified using the forward primer L-CO1 (5'TTT TTT GGG CAT CCT GAG GTT TAT- $3^{\prime}$ ) and the reverse primer $\mathrm{H}$-COX1 (5'-TAA AGA AAG AAC ATA ATG AAA ATG-3') [19].

Each PCR reaction had a final volume of $35 \mu \mathrm{l}$ including: 5 standard units of GoTaq DNA polymerase (Promega, Madison, USA), $7 \mu \mathrm{l} 5 \times$ PCR buffer, $5.6 \mu \mathrm{l} \mathrm{\textrm {MgCl } _ { 2 }}$ $(25 \mathrm{mM}), 2.1 \mu \mathrm{l} \mathrm{BSA}(10 \mathrm{mg} / \mathrm{ml}), 0.7 \mu \mathrm{l}$ of deoxynucleotide triphosphate (dNTP) $(10 \mathrm{mM}), 10 \mathrm{pM}$ of each primer and $7 \mu \mathrm{l}$ template DNA. A Boeco Ecogermany M-240R Thermal Cycler (Boeckel, Hamburg, Germany) was used with a cycling profile as follows: 30 temperature cycles programmed on a slow temperature ramp rate. Cycle 1 was $95^{\circ} \mathrm{C}$ for $3 \mathrm{~min}, 45^{\circ} \mathrm{C}$ for 2 min and $72^{\circ} \mathrm{C}$ for $90 \mathrm{~s}$. This was followed by four cycles of $95{ }^{\circ} \mathrm{C}$ for $45 \mathrm{~s}$, $50{ }^{\circ} \mathrm{C}$ for $45 \mathrm{~s}$ and $72{ }^{\circ} \mathrm{C}$ for $90 \mathrm{~s}$, then a further 25 cycles of $95^{\circ} \mathrm{C}$ for $20 \mathrm{~s}, 52^{\circ} \mathrm{C}$ for $20 \mathrm{~s}$ and $72{ }^{\circ} \mathrm{C}$ for $90 \mathrm{~s}$. The mix was held at $72{ }^{\circ} \mathrm{C}$ for $5 \mathrm{~min}$ to complete extension and then dropped to $4{ }^{\circ} \mathrm{C}$. For cox 1 PCR, there was an initial denaturation step at $95{ }^{\circ} \mathrm{C}(5 \mathrm{~min})$ followed by 35 cycles of $95^{\circ} \mathrm{C}$ for $1 \mathrm{~min}, 48{ }^{\circ} \mathrm{C}$ for $2 \mathrm{~min}$ and $72{ }^{\circ} \mathrm{C}$ for $21 \mathrm{~min}$ ) with a final extension step at $72{ }^{\circ} \mathrm{C}$ for $10 \mathrm{~min}$. PCR products were directly sequenced (Macrogen, Seoul, Korea; http://www.macrogen.com).

Sequences were edited and assembled using ProSeq v2.9 [20]. The fragments obtained from the $L S U$ rRNA gene were aligned using the Clustal 2 [21] software package with sequences of related monogeneans retrieved from GenBank (Table 1). All new DNA sequences were deposited in the GenBank database, and the accession numbers are given in Table 1.

Phylogenetic reconstruction was performed using Bayesian inference (BI) and maximum-likelihood (ML) analyses. jModelTest 0.1.1 software [22] was employed to determine the best-fit nucleotide substitution model under the Akaike information criterion AIC [23]. For $L S U$ rRNA and cox 1 genes, the models GTR $+\mathrm{G}$ and GTR + I, respectively, were used as optimal models. For $\mathrm{BI}$, unique random starting trees were used in the Metropolis-coupled Markov chain Monte Carlo (MCMC [24]. For both genes, independent MCMC chains were run with 50,000,000 of generations, sampling every 1000 generations, obtaining effective samples sizes (ESS) of parameter estimates over 200. Results were visualized in TRACER v. 1.7 [25]. ML analysis was performed using the MEGA v.6 considering gaps [26], missing data, pairwise deletions, codon positions, and 1st $+2 \mathrm{nd}+3 \mathrm{rd}+$ noncoding positions. Nodal support was estimated by bootstrapping $(n=1000)$.

The sequences of the monogeneans Amphibdellatidae gen. sp. (GenBank: FJ971964) and Neocalceostoma sp. (GenBank: AF387510) were used as the outgroup for $L S U$ rRNA phylogenetic tree $[27,28]$. No sequences for cox 1 gene are available on GenBank for potential outgroups in the phylogenetic tree. Pairwise p-distances were also calculated with MEGA v6.

\section{Results \\ Class Monogenea (van Beneden, 1858)}

Family Acanthocotylidae Monticelli, 1903

\section{Genus Acanthocotyle Monticelli, 1888}

\section{Acanthocotyle imo n. sp.}

Type-host: Amblyraja frerichsi (Krefft) (Rajiformes: Rajidae), thickbody skate.

Type-locality: Off Tocopilla, northern Chile $\left(22^{\circ} 16^{\prime} \mathrm{S}\right.$, $70^{\circ} 38^{\prime} \mathrm{W}-23^{\circ} 26^{\prime} \mathrm{S}, 70^{\circ} 43^{\prime} \mathrm{W}$ ) at $c .1500 \mathrm{~m}$ depth.

Type-material: The holotype (NMHH-SI 1480277) and 2 paratypes (NMNH-SI 1480278-9) were submitted to the National Museum of Natural History, Smithsonian Institution, Washington D.C., USA; 2 paratypes (MHN-UNMSM 3645-3646) were submitted to the Museo de Historia Natural, Universidad Nacional Mayor de San Marcos, Lima, Peru; and 2 paratypes (NHMUK 2018.8.30.1-2,) were submitted to the Natural History Museum, London, UK.

Site on host: Skin.

Prevalence and intensity: Prevalence: 100\%; mean intensity: 2.8 . 
Table 1 GenBank accession numbers for sequences (LSU rRNA gene and cox1 gene) for Acanthocotyle spp. and the species of the outgroup used in phylogenetic analyses

\begin{tabular}{|c|c|c|c|c|c|}
\hline \multirow[t]{2}{*}{ Species } & \multirow[t]{2}{*}{ Host } & \multirow[t]{2}{*}{ Locality } & \multicolumn{2}{|l|}{ GenBank ID } & \multirow[t]{2}{*}{ References } \\
\hline & & & LSU rRNA & $\operatorname{cox} 1$ & \\
\hline A. atacamensis n. sp. & $\begin{array}{l}\text { Bathyraja peruana } \\
\text { McEachran \& Myyake }\end{array}$ & $\begin{array}{l}\text { Off Tocopilla, northern Chile } \\
\left(22^{\circ} 16^{\prime} \mathrm{S}, 70^{\circ} 38^{\prime} \mathrm{W}-23^{\circ} 26^{\prime} \mathrm{S},\right. \\
\left.70^{\circ} 43^{\prime} \mathrm{W}\right)\end{array}$ & MH511079-MH511082 & MH511067-MH511072 & This study \\
\hline $\begin{array}{l}\text { A. gurgesiella Ñacari, } \\
\text { Sepúlveda, Escribano \& } \\
\text { Oliva, } 2018\end{array}$ & $\begin{array}{l}\text { Gurgesiella furvescens de } \\
\text { Buen }\end{array}$ & $\begin{array}{l}\text { Off Valparaiso, central Chile } \\
\left(33^{\circ} \mathrm{S}, 72^{\circ} \mathrm{W}\right)\end{array}$ & KY379328-KY379329 & KY379330-KY379331 & [10] \\
\hline A. imon. sp. & Amblyraja frerichsi (Krefft) & $\begin{array}{l}\text { Off Tocopilla, northern Chile } \\
\left(22^{\circ} 16^{\prime} \mathrm{S}, 70^{\circ} 38^{\prime} \mathrm{W}-23^{\circ} 26^{\prime} \mathrm{S},\right. \\
\left.70^{\circ} 43^{\prime} \mathrm{W}\right)\end{array}$ & MH511083-MH511085 & MH511074-MH511078 & This study \\
\hline $\begin{array}{l}\text { A. urolophi Kearn, Whit- } \\
\text { tington, Chisholm \& } \\
\text { Evans-Gowing, } 2016\end{array}$ & $\begin{array}{l}\text { Urolophus cruciatus } \\
\text { (Lacépède) }\end{array}$ & Tasman Sea (off Australia) & FJ971962 & & [11] \\
\hline \multicolumn{6}{|l|}{ Outgroup } \\
\hline Amphibdellatidae gen. sp. & $\begin{array}{l}\text { Narcine tasmaniensi (Rich- } \\
\text { ardson) }\end{array}$ & Off Australia & FJ971964 & & [23] \\
\hline Neocalceostoma sp. & Arius venosus Valenciennes & Off Malaysia & AF387510 & & [24] \\
\hline
\end{tabular}

Representative DNA sequences: MH511083-MH511085 (LSU rRNA gene); MH511074-MH511078 (cox1 gene).

Etymology: The specific name refers to the Instituto Milenio de Oceanografia (IMO), Chile, in appreciation of the financial and logistic support.

\section{Description}

[Measurements based on 21 adult worms. Metrical data and meristic counts were taken for each parasite (Table 2). Raw measurements are given in Additional file 1: Table S1.] Total body length, including pseudohaptor 3418-8434 (5600); maximum body width 512-1440 (867) (Fig. 1a). True haptor with 16 marginal hooks (14 peripheral and 2 central) (Fig. 1c) located at posterior margin of pseudohaptor. Pseudohaptor nearly circular, 704-1473 (1086) in length and 667-1466 (1038) in width, with 30-35 (mode 32) rows of sclerites with sharp recurved tips (Fig. 1b); rows are easily counted peripherally; each row consists of 6-10 sclerites [total number 268-314 (292)] (Fig. 1b). Marginal valve of pseudohaptor smooth. Pharynx globular, 163-354 × 132-388 $(248 \times 231)(n=20)$. Three anterior adhesive lobes present on each side of anterior extremity, with a single aperture. Sensory organs conspicuous, at or near anterior margin of head. Excretory bladders 2, anterior to vitellarium field on each side of body. More or less pronounced constriction (or neck) present at level of posterior margin of pharynx, marking off head region from body proper. Intestinal caeca without diverticula, not confluent. Eyes absent. Testes mainly rounded, 32-47 (mode 41) in number, posterior to germarium, usually arranged in 2 rows, $92-234 \times 80-213(151 \times 138)$. Vas deferens connecting posterior seminal vesicle slightly lobed; anterior seminal vesicle smooth, communicates with male genital opening via relatively large, curved ejaculatory duct; male accessory gland reservoirs 2, adjacent to ejaculatory duct (Fig. 1d). Penis unarmed; male genital opening unarmed, slightly dextral, at level of intestinal bifurcation. Germarium subglobular 104-412 (236, $n=17)$ long, 149-352 (219, $n=19)$ wide. Uterine seminal receptacle $104-294 \times 98-246(199 \times 173)(n=16)$, contiguous with germarium; vagina absent. Germinal appendix not observed. Opening of uterine atrium dextral and dorsal, at level of posterior part of pharynx (Fig. 1d). Eggs sausage-shaped, $220-380 \times 60-110(290 \times 80) \quad(n=11)$, with abopercular appendages, 90-210 (120, $n=11)$. Eggs (Fig. 1e) observed in 11 specimens, but each one harbored only one egg. Vitellarium extracaecal, consisting of numerous elongated, non-discrete follicles, extending from level of posterior seminal vesicle to near posterior end of body proper.

\section{Differential diagnosis}

Acanthocotyle imo n. sp. is morphologically similar to $A$. verrilli and $A$. gurgesiella, species with a pseudohaptor armed with 21-39 radial rows of sclerites, having a dextral opening of uterine atrium, non-discrete vitelline follicles, and more than 20 testes [11]. The number of radial rows of sclerites has been reported to range from 30 to 34 in $A$. verrilli [11] and between 36-40 (mode 40) in $A$. gurgesiella [vs 30-35 (mode 32$)]$ in the new species. The number of testes in the new species (32-47; mode 41) agree well with values given for $A$. verrilli (range from 37 
Table 2 Meristic and morphometric data for Acanthocotyle spp. from off northern Chile

\begin{tabular}{|c|c|c|c|}
\hline Species & A. imo n. sp. & A. atacamensis n. sp. & $\begin{array}{l}\text { A. gurgesiella Ñacari, } \\
\text { Sepúlveda, Escribano \& } \\
\text { Oliva, } 2018\end{array}$ \\
\hline Host & Amblyraja frerichsi & Bathyraja peruana & Gurgesiella furvescens \\
\hline Source & $\begin{array}{l}\text { Present study }(n=21) \\
\text { Range (mean) }\end{array}$ & $\begin{array}{l}\text { Present study }(n=21) \\
\text { Range (mean) }\end{array}$ & $\begin{array}{l}\text { Nacari et al. [10] }(n=10) \\
\text { Range (mean) }\end{array}$ \\
\hline Body length & $3418-8434(5600)$ & $2571-7702(5087)$ & $3070-5720(4190)$ \\
\hline Maximum body width & $512-1440(867)$ & 292-931 (689) & $630-1180(940)$ \\
\hline Pharynx length & $163-354(248)$ & $186-346(262)$ & $110-330(240)$ \\
\hline Pharynx width & $132-388(231)$ & $152-309(234)$ & $150-360(250)$ \\
\hline Pseudohaptor length & $704-1473(1086)$ & 487-1085 (862) & $600-1100(890)$ \\
\hline Pseudohaptor width & $667-1466(1038)$ & $416-1075(840)$ & $640-1250(910)$ \\
\hline No. of sclerite rows in pseudohaptor & 30-35 (mode 32) & 28 & 36-40 (mode 38) \\
\hline Total no. of sclerites in pseudohaptor & $268-314(292)$ & $186-240(220)$ & 201-331 (270) \\
\hline No. of testes & 32-47 (mode 41) & 40-58 (mode 50) & 28-43 (mode 35) \\
\hline Maximum testis width & $80-213(138)$ & $186-346(262)$ & $30-80(70)$ \\
\hline Germarium length & $104-412(236)$ & $75-243(159)$ & $130-280(240)$ \\
\hline Germarium width & 149-352 (219) & $141-267(204)$ & $160-290(240)$ \\
\hline Seminal receptacle length & 104-294 (199) & $111-269(193)$ & 63 \\
\hline Seminal receptacle width & $98-246(173)$ & $103-216(150)$ & 54-62 (59) \\
\hline Egg length & 218-381 (287) & $305-336(321)$ & - \\
\hline Egg width & $56-113(76)$ & 64-93 (79) & - \\
\hline
\end{tabular}

to $c .57)[29,31]$ and $A$. gurgesiella (28-43) [10], but the mode (30) for the latter species is lower than for A. imo n. sp. The testes in $A$. verrilli are arranged in numerous rows (vs mainly in two rows in $A$. imo n. sp. and A. gurgesiella). The ratio total length/pseudohaptor is higher in the new species (4.61-5.86) compared with $A$. verrilli (2.48-2.86) $[29,31]$, but similar to the ratio in A. gurgesiella (4.375.10) [10]. The presence of a smooth marginal valve of the pseudohaptor in $A$. imo n. sp. instead of a marginal valve with a distinct fringe in $A$. verrilli is an additional difference between the two species. Acanthocotyle imo n. sp. can be readily differentiated from $A$. gurgesiella by the lack of a spear-shaped spine in penis (present in the latter species) (see Fig. 2 and Additional file 2: Table S2).

\section{Acanthocotyle atacamensis n. sp.}

Type-host: Bathyraja peruana McEachran \& Miyake, 1984 (Rajiformes: Arhynchobatidae), Peruvian skate.

Type-locality: Off Tocopilla, northern Chile $\left(22^{\circ} 16^{\prime} \mathrm{S}\right.$, $\left.70^{\circ} 38^{\prime} \mathrm{W}-23^{\circ} 26^{\prime} \mathrm{S}, 70^{\circ} 43^{\prime} \mathrm{W}\right)$, at c. $1500 \mathrm{~m}$ depth.

Type-material: The holotype (NMNH-SI 1480280) and 2 paratypes (NMNH-SI 1480281-2) were submitted to the National Museum of Natural History, Smithsonian
Institution, Washington D.C., USA; 2 paratypes (MHNUNMSM 3643-3644) were submitted to the Museo de Historia Natural, Universidad Nacional Mayor de San Marcos, Lima, Peru; and 2 paratypes (NHMUK 2018.8.30.3-4,) were submitted to the Natural History Museum, London, UK.

\section{Site on host: Skin.}

Prevalence and intensity: Prevalence: 100\%; Mean intensity: 3.0.

\section{Representative DNA sequences: MH511079-MH511082} (LSU rRNA gene); MH511067-MH511072 (cox1 gene).

Etymology: The specific name of the new species refers to the Atacama trench where samples were obtained.

\section{Description}

[Measurements based on 21 adult worms. Metrical data and meristic counts were taken for each parasite (Table 2). Raw measurements are given in Additional file 3: Table S3.] Total body length, including pseudohaptor 2571-7702 (5087); maximum body width 292-931 (689) (Fig. 3a). True haptor with 16 marginal hooks (14 peripheral and 2 central) (Figs. 3c, 4) located at posterior margin of pseudohaptor (Fig. 3b). 


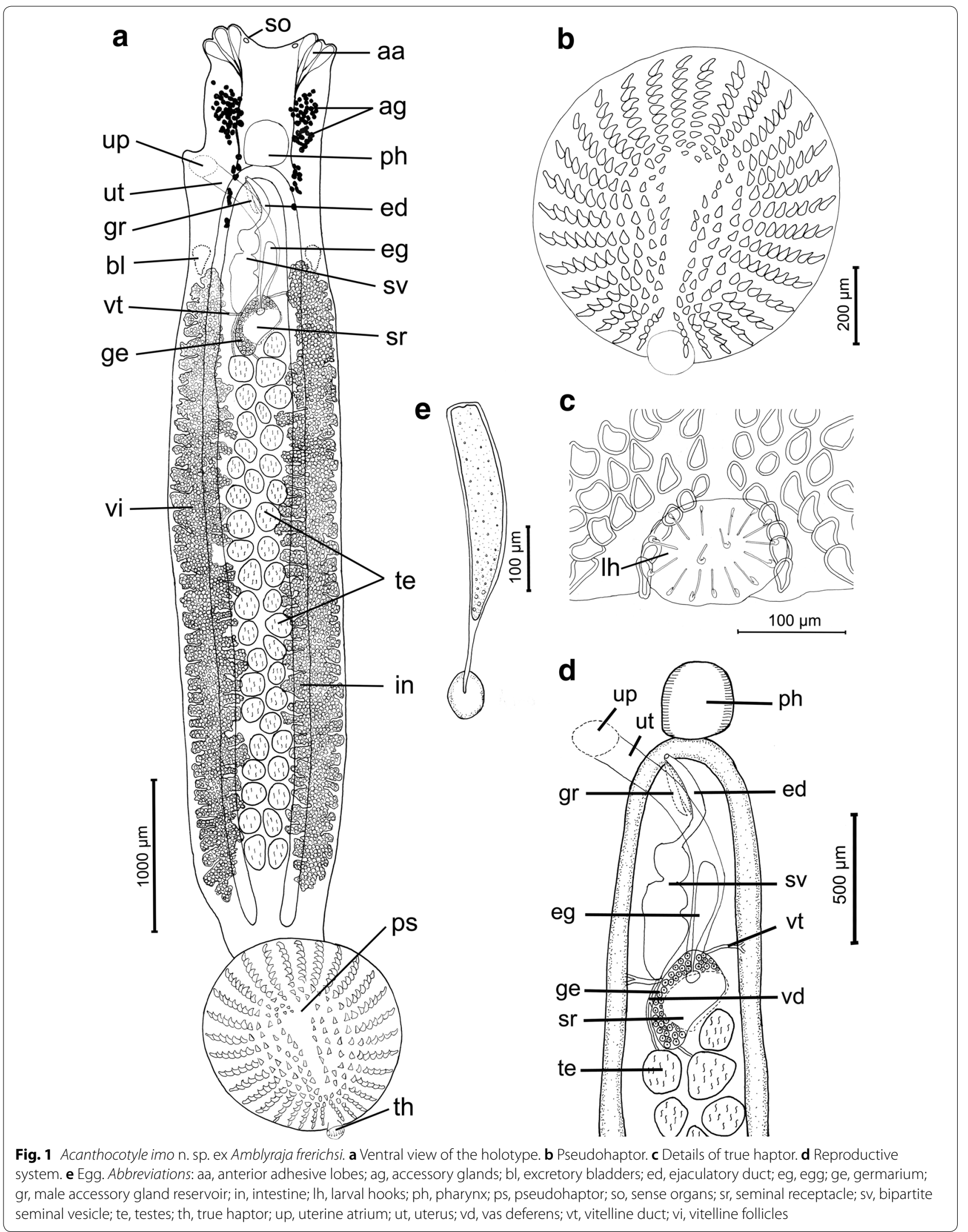


Pseudohaptor nearly circular, 487-1085 (862) in length by $416-1075$ (840) in width, with 28 rows of sclerites with sharp recurved tips (Fig. $3 \mathrm{~b}$ ); rows are easily counted peripherally; each row consists of 6-10 sclerites [total number 186-240 (220)] (Fig. 3b). Marginal valve of pseudohaptor with distinct fringe (Fig. 3b). Pharynx globular, $185-346 \times 152-309 \quad(262 \times 234)$ $(n=20)$. Three anterior adhesive lobes present on each side of anterior extremity, with a single aperture. Sensory organs conspicuous at or near anterior margin of head. Excretory bladders 2, anterior to vitellarium field on each side of the body. More or less pronounced constriction (or neck) present at level of posterior margin of pharynx, marking off head region from body proper. Intestinal caeca without diverticula. Eyes absent. Testes irregular in shape, 40-58 (mode 50) in number, posterior to germarium, usually arranged in 3 rows, $70-178 \times 41-131(122 \times 92)$. Vas deferens expands conforming unlobed posterior seminal vesicle and anterior unlobed seminal vesicle that communicates with male genital opening via relatively large, curved ejaculatory duct; male accessory gland reservoirs 2, adjacent to ejaculatory duct (Fig. 3d). Penis unarmed; male genital opening unarmed, slightly dextral, at level of intestinal bifurcation. Germarium subglobular, 75-243 (149, $n=19)$ long, 141-267 (204) $(n=19)$. Uterine seminal receptacle $111-279 \times 103-$ $216(193 \times 150) \quad(n=16)$, contiguous with germarium; vagina absent. Germinal appendix not observed. Opening of uterine atrium dextral and dorsal, at level of posterior part of pharynx (Fig. 3d). Eggs sausageshaped, $305-336 \times 64-93(321 \times 79)(n=2) \quad($ Fig. 3e) with abopercular appendages 111-116 (114) $(n=2)$. Eggs observed in 2 specimens, but each one harbored only one egg. Vitellarium extracaecal, consisting of numerous elongate follicles, extending from the level of the posterior external seminal vesicle to near the posterior end of body proper.

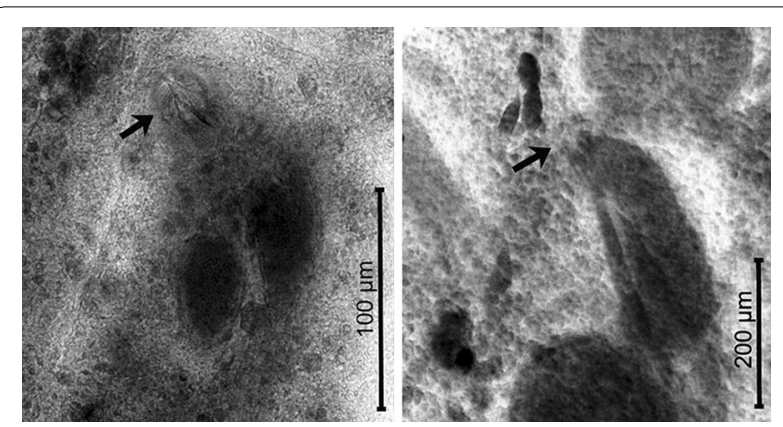

Fig. 2 Photomicrography of penis armed with spear-shaped spine in Acanthocotyle gurgesiella (left, arrow) and unarmed penis in A. imo (right, arrow)

\section{Differential diagnosis}

Acanthocotyle atacamensis n. sp. resembles morphologically $A$. verrilli and $A$. imo n. sp. characterized by possessing more than 10 testes, a pseudohaptor armed with 21-40 radial rows of sclerites, a dextral opening uterine atrium and non-discrete vitelline follicles [11]. The number of the testes overlaps in the three species: $37-c .57$ in A. verrilli $[29,30]$; 32-47 (mode 41) in A. imo n. sp.; and 40-58 (mode 50) in A. atacamensis n. sp. The main differences with $A$. verrilli and $A$. imo n. sp. include the number of radial rows of sclerites ranging between 30-34 in A. verrilli, 30-35 in A. imo n. sp. instead of 28 (no variation) in $A$. atacamensis. Similarly, the total number of sclerites is greater in A. verrilli (387) and $A$ imo (268-314) than in A. atacamensis n. sp. (186-240). Additionally, the ratio TL/pseudohaptor is greater in $A$. atacamensis n. sp. (5.03-7.80) and A. imo n. sp. (4.61-5.86) than in $A$. verrilli (2.76-2.86), indicating a pseudohaptor that is proportionally larger in $A$. verrilli. A summary of the morphological and morphometric characteristics of the species of Acanthocotyle considered valid are provided in Additional file 2: Table S2.

Notably, the three species of Acanthocotyle from the SPO harbored a single egg and not egg bundles as indicated for other species in the genus.

\section{Morphometric analysis}

Figure 5 presents a plot of the specimens in the twodimensional plane of the PCA. The first and second components of the PCA explained $64.86 \%$ of the total variance. The first component explaining $49.67 \%$ of the variance was associated with the proportional morphometric measurements of body width/TL, body length (excluding pseudohaptor)/TL, pharynx width/TL and germarium length/TL, whereas the second component explaining $15.19 \%$ of the variance was associated with pharynx length/TL, testes width/TL and germarium width/TL.

The results of the multivariate discriminant analysis (MDA) (Table 3) showed a correct assignment for the three species that, on average, reached $93.5 \%$ of the studied specimens of Acanthocotyle (Wilk's lambda $=0.78$, $\left.F_{(10,78)}=20.17, P<0.001\right)$. The probability of correct assignment by chance alone was $36.2 \%$.

\section{Molecular and phylogenetic analyses}

For the LSU rRNA region, seven sequences of $862 \mathrm{bp}$ were obtained ( 4 from $A$. atacamensis n. sp. and 3 from $A$. imo n. sp.). Intraspecific genetic variability for both $A$. imo and $A$. atacamensis was $0 \%$. Sequences were aligned and trimmed to $409 \mathrm{bp}$ (the size of sequences available on GenBank) in order to compare the new species with 


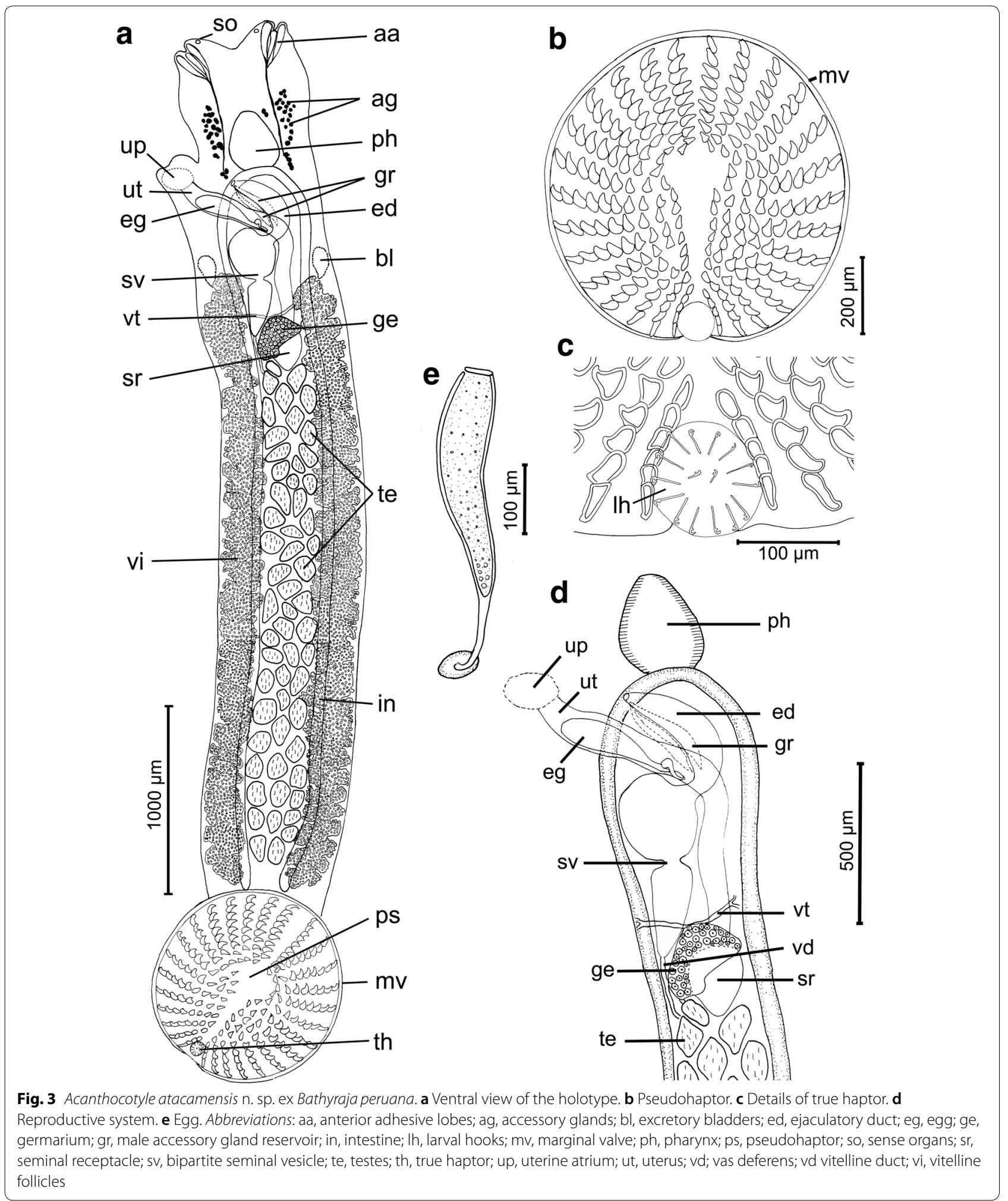




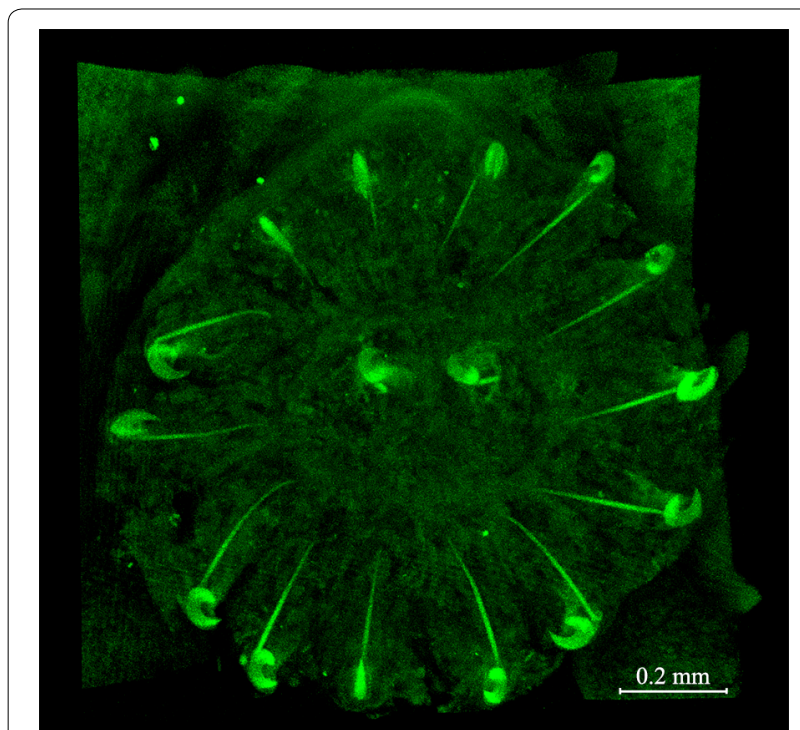

Fig. 4 Confocal image of the pseudohaptor of A. atacamensis n. sp. ex Bathyraja peruana

A. gurgesiella and A. urolophi. Genetic distances between the new species and A. gurgesiella and A. urolophi are shown in Table 4.
Eleven sequences of the cox 1 gene were obtained: 6 from $A$. atacamensis n. sp. (713 bp); 5 from $A$. imo n. sp. (669 bp); 2 published sequences from $A$. gurgesiella (424 bp) [10] were also included in analysis. Intraspecific variability ranged from between $0-0.7 \%$ ( 5 polymorphic sites) for $A$. atacamensis n. sp., $0-0.3 \%$ for $A$. imo n. sp. (3 polymorphic sites) and $0.5 \%$ for $A$. gurgesiella ( 2 polymorphic sites). Sequences were aligned and trimmed to 307 bp for comparison with A. gurgesiella. Genetic distances between the two new species and A. gurgersiella are shown in Table 4.

The trees in Fig. 6 show the phylogenetic relationships based on the $L S U$ rRNA and $\operatorname{cox} 1$ genes for members of Acanthocotyle. LSU rRNA gene suggest that sequences from conspecific specimens of Acanthocotyle spp. clustered together in a single monophyletic clade, supported by high posterior probability $(\mathrm{BI}=1)$ and high bootstrap support value from the ML analysis $(\mathrm{ML}=100)$. $L S U$ rRNA data did not support reciprocal monophyly of $A$. imo n. sp. but this was supported by the more variable mitochondrial gene, cox 1 . Unrooted $\operatorname{cox} 1$ tree in Fig. 6 shows the sequences of the two new species from South-East Pacific (A. atacamensis n. sp. and

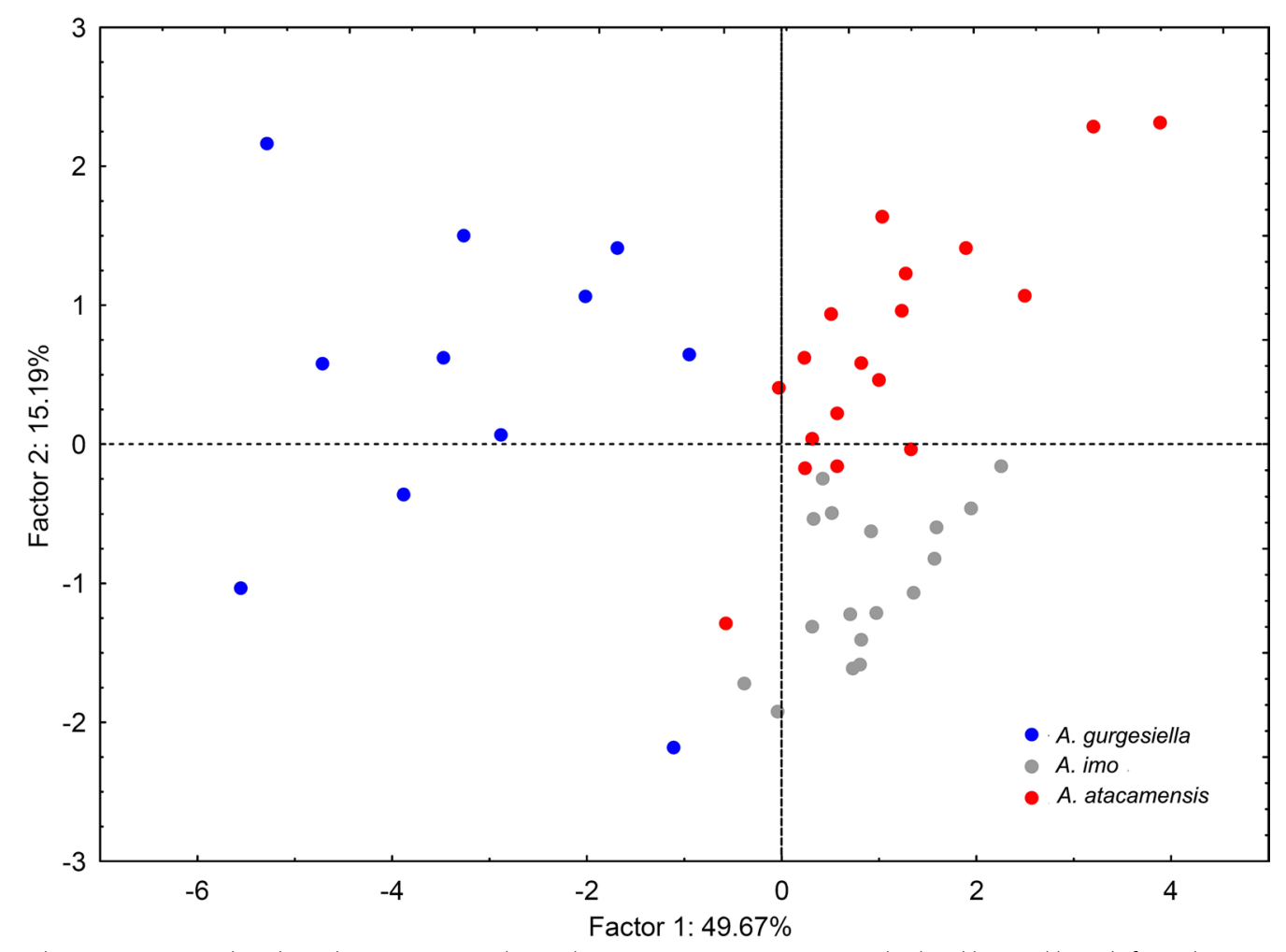

Fig. 5 Principal components analysis based on proportional morphometric measurements standardized by total length from three species of Acanthocotyle from off northern Chile. Blue circles: A. gurgesiella ex Gurgesiella furvescens; grey circles: A. imo n. sp. ex Amblyraja frerichsi; red circles: A. atacamensis n. sp. ex Bathyraja peruana 
Table 3 Classification matrix of the multivariate discriminant analysis, based on morphometrics proportion standardized by total length of three species of Acanthocotyle from the SouthEast Pacific Ocean

\begin{tabular}{lllll}
\hline Species & $\begin{array}{l}\text { A. imo } \\
(P=0.37)\end{array}$ & $\begin{array}{l}\text { A. atacamensis } \\
(P=0.41)\end{array}$ & $\begin{array}{l}\text { A. gurgesiella } \\
(P=0.22)\end{array}$ & $\begin{array}{l}\text { \% Correct } \\
\text { classification }\end{array}$ \\
\hline A. imo & 16 & 1 & 0 & 94.1 \\
A. atacamensis & 1 & 18 & 0 & 94.7 \\
A. gurgesiella & 1 & 0 & 9 & 90.0 \\
Total & 18 & 19 & 9 & 93.5 \\
\hline
\end{tabular}

Note: Pairwise probabilities all $<0.001$

A. imo n. sp.) and A. gurgesiella forming three well supported clades.

\section{Discussion}

Traditional taxonomy based on morphology and morphometry and multivariate analyses based on morphometric data corrected for body length, strongly supports three species of Acanthocotyle detected in three different skates (all members of Rajiformes) from SPO (off Tocopilla, northern Chile). $L S U$ rRNA data did not support reciprocal monophyly for $A$. imo n. sp. but this was supported by the cox 1 gene data. Absence of reciprocal monophyly could be a consequence of a short length of the studied fragment and/or the gene may not be variable enough to reflect recent divergence.

The lack of molecular data from almost all members of Acanthocotyle (except for A. urolophi and A. gurgesiella) precludes the molecular confirmation of the species described herein, but morphological characteristics of the new species are robust enough to confirm their distinct status. The two new species are easily differentiated from their congeners by a combination of characteristics that includes morphometric and morphological characters as indicated in the differential diagnosis for each species.

Including the two new species described above, Acanthocotyle, the unique genus in the Acanthocotylidae, now

Table 4 Percent pairwise genetic distances between Acanthocotyle spp. for LSU rRNA gene (under the diagonal) and the mitochondrial cox1 gene (above the diagonal)

\begin{tabular}{llll}
\hline & A. atacamensis $(n=6)$ & A. imo $(n=5)$ & A. gurgesiella $(n=2)$ \\
\hline A. atacamensis $(n=4)$ & - & $14.3-15.6$ & $18.8-19.5$ \\
A. imo $(n=3)$ & 0.50 & - & $21.5-21.8$ \\
A. gurgesiella $(n=2)$ & $2.24-2.74$ & $1.75-2.24$ & - \\
A. urolophi $(n=1)$ & 2.99 & 2.74 & $3.24-3.74$
\end{tabular}

Notes: Comparisons are based on $409 \mathrm{bp}$ (LSU rRNA gene) and $307 \mathrm{bp}$ (cox1). Numbers in parentheses indicate the number of sequences used for the comparisons (LSU rRNA gene, first column; cox1, first line)

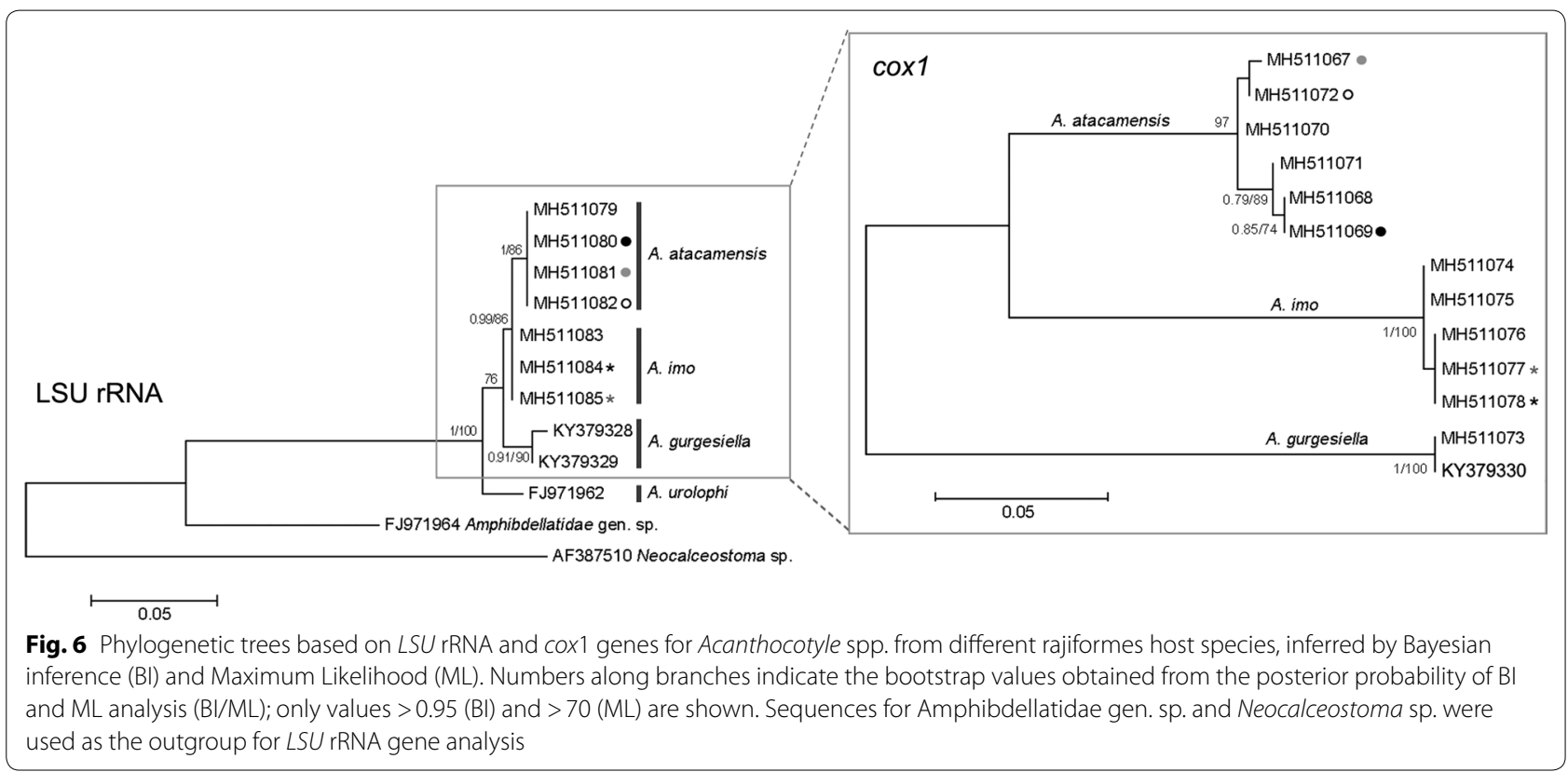




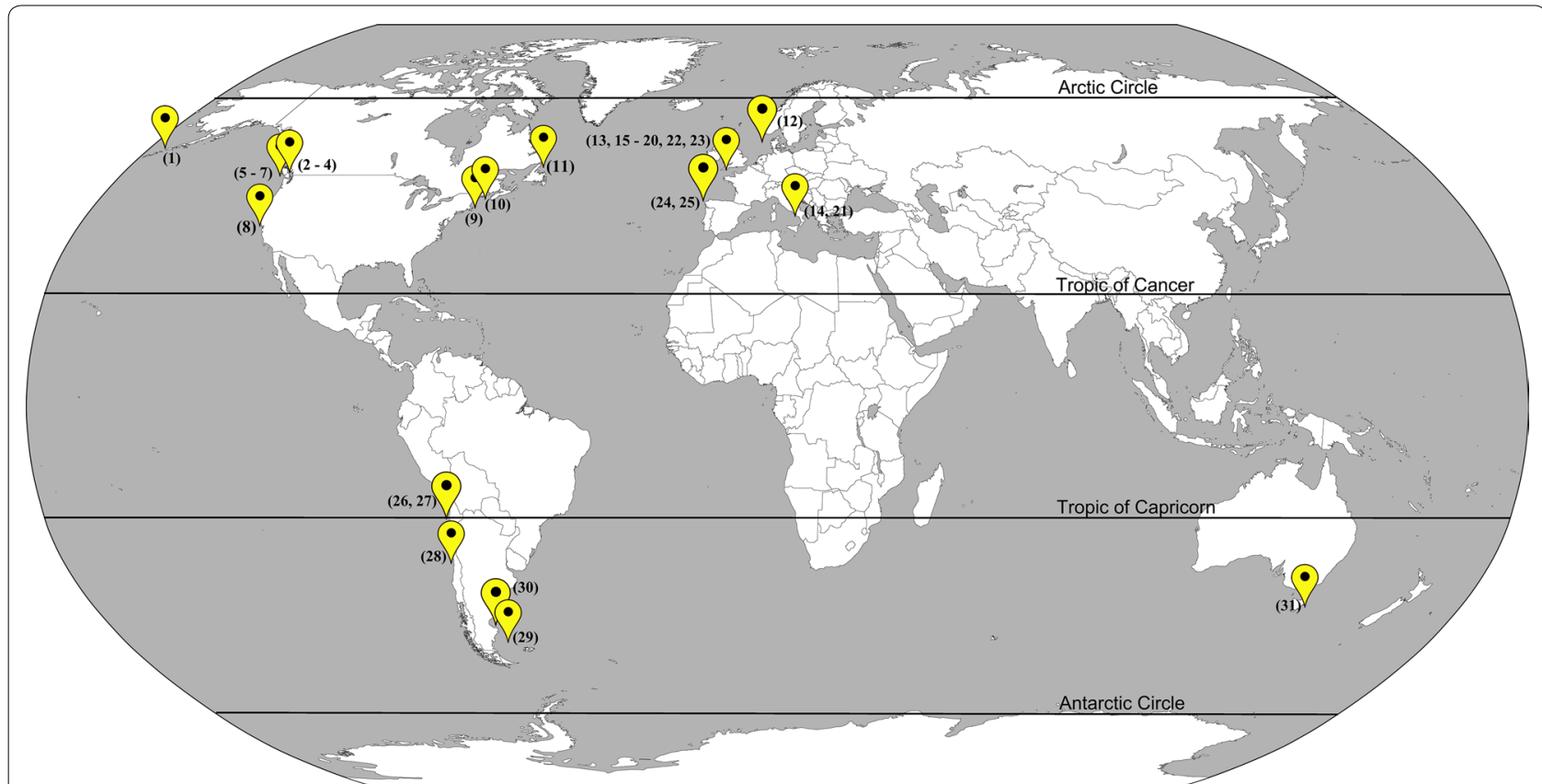

Fig. 7 Distribution map of the known species of Acanthocotyle. Key: 1, A. williamsi ex unidentified skate, Bering Sea; 2, A. pacifica ex Beringraja binoculata, Puget Sound; 3, A. pacifica ex Raja rhina, Puget Sound, USA; 4, A. pacifica ex Raja stellulata, Puget Sound, USA; 5, A. pacifica ex B. binoculata, Friday Harbour, USA; 6, A. pacifica ex R. rhina, Friday Harbour, USA; 7, A. pugetensis ex B. binoculata, Friday Harbour, USA; 8, A. pugetensis ex B. binoculata, off San Francisco USA; 9, A. verrilli ex unidentified skate, Cape Cod, USA; 10, A. verrilli ex Leucoraja erinacea, off Maine, USA; 11, A. verrilli ex Amblyraja radiata, off Newfoundland, Canada; 12, A. verrilli ex A. radiata, continental slope between northern Norway and Spitsbergen; 13, $A$. grenii ex Raja clavata, off Plymouth, UK; 14, A. lobianchi ex R. clavata, off Naples, Italy; 15, A. Iobianchi ex Bathyraja brachyurops, off Plymouth, UK; 16, A. lobianchi ex Raja microocellata, off Plymouth, UK; 17, A. lobianchi ex R. clavata, off Plymouth, UK; 18, A. lobianchi ex Raja montagui, off Plymouth, UK; 19. A. lobianchi ex Leucoraja naevus, off Plymouth, UK; 20, A. elegans ex R. clavata, off Plymouth, UK; 21, A. elegans ex R. clavata, off Naples, Italy; 22, Acanthocotyle sp. ex R. clavata, off Plymouth, UK; 23, Acanthocotyle sp. ex Narcine maculata, off Plymouth, UK; 24, Acanthocotyle sp. ex R. microocellata Atlantic continental shelf off the mouth of the estuary Muros e Noia, Spain; 25, Acanthocotyle sp. ex B. brachyurops Atlantic continental shelf off the mouth of the estuary Muros e Noia, Spain; 26 A. imo n. sp. ex Amblyraja frerischi, off Tocopilla, Chile; 27, A. atacamensis n. sp. ex Bathyraja peruana, off Tocopilla, Chile; 28, A. gurgesiella ex Gurgesiella furvescens off Valparaiso, Chile; 29, A. patagonica ex B. brachyurops, Patagonian Shelf, Falkland Islands, UK; 30, Acanthocotyle sp. ex Sympterygia bonapartii, off Puerto Deseado, Argentina; 31, A. urolophi ex Urolophus cruciatus, off Tasmania, Australia

comprises 12 valid species. Only two species have been reported from hosts other than Rajiformes: A. urolophi described from Urolophus cruciatus (Myliobatiformes) [11] and Acanthocotyle sp. recorded from Raja clavata but also Narcine maculata (Torpediniformes); no differences between specimens obtained from the two hosts were indicated [12]. The presence of Acanthocotyle sp. in $N$. maculata could be the result of a transfer of the parasite between fishes during capture. A similar reason was suggested to explain the presence of $A$. williamsi (as Pseudacanthocotyla williamsi) in the teleost Sebastes alutus (Gilbert) (Scorpaeniformes) [32]. Surprisingly, this species was also recorded from the gills of another teleost fish, Reinhardtius hippoglossoides (Walbaum) (Pleuronectiformes) [33]. Unfortunately, we were unable to find additional records of $A$. williamsi in order to check the identity of the host. A different picture is evident for A. verrilli, also described originally for a "skate" but at least seven records, from four members of the Rajidae, are available. Species of Acanthocotyle seem to be specific to members of the Rajidae, but this assumption must be treated with caution. During 2016, three major contributions to the taxonomy of elasmobranchs were published [34-36]. Accordingly, hosts for Acanthocotyle are included not only in the Rajidae [32] but also in the Arhynchobatidae [34, 35]. The specificity of Acanthocot$y l e$, at least at the family level, requires clarifying the systematics of the Rajiformes.

The integration of both, molecular and morphological tools and discriminant morphometric characters has strongly strengthened the traditional taxonomy, resolving the existence of cryptic species, identification of new species, and also clarification of species taxonomic status [16, 37-39]. Thus, our findings, based on molecular and morphometric multivariate analysis, are strongly consistent. The results of PCA and $\operatorname{cox} 1$ genes support the same conclusion: the species that are closer in the first plane of the PCA plot (A. imo n. sp. and A. atacamensis n. sp., see 
Fig. 5), also appear closer in the phylogenetic tree based on cox 1 but reciprocal monophyly for $A$. imo is not supported by $L S U$ rRNA (Fig. 6). These results clearly suggest the key importance of integrating molecular and multivariate morphometric analyses for taxonomic studies.

The analysis of the geographical distribution of members of Acanthocotyle suggests a close association with the temperate region (Fig. 7), although this conclusion should be considered with caution. To date, all known species have been described from fishes of two families of the Rajiformes (Rajidae and Arhynchobatidae), except for A. urolophi and Acanthocotyle sp. (Myliobatiformes and Torpediniformes, respectively). Regarding hosts of the Rajiformes, a search in the ISI Web of Sciences (1975-2018) and Scopus (1990-2018), using as search criteria "Rajidae", "Rajiformes" and "parasites", yielded 46 references (excluding records from freshwater Rajiformes) that include parasitological records for just 61 host species. The known species count of Rajiformes is 287 [36], and the geographical range of distribution of members of this order includes from tropical to polar seas, and from shallow to deep-waters in the Atlantic, Indian and Pacific Ocean [32] and only 14 species of Rajiformes have been recorded as host for members of Acanthocotyle. As stated in a previous study [40], Rajidae have particularly been neglected in terms of limited sampling effort when studying cestodes. This limitation also applies to other parasites, such as the monogeneans, and therefore clarifying patterns of distribution will require a substantial increase in research effort, particularly for deep-sea hosts. The current distribution of members of Acanthocotyle (Fig. 7) can thus be explained by intensive sampling effort in some localities, specifically off the Pacific and Atlantic coasts of North America and the English Channel. It is early to consider host specificity of Acanthocotyle even more if c.104 species of Rajidae are considered as deep-sea skates [41], and only four species (including this record) have been studied as host for species in Anthocotyle.

\section{Conclusions}

Two new species of the genus Acanthocotyle are described from the skin of two deep-sea skates (Rajiformes) obtained at a depth of $c .1500 \mathrm{~m}$ off Tocopilla (northern Chile). Both species represent the deepest record for members of Acanthocotyle. Conclusions about host specificity as well as geographical distribution of Acanthocotyle should be treated with caution due to the low proportion of Rajiformes studied for monogeneans. Acanthocotyle spp. have been recorded for 14 of the 287 species in Rajiformes. Future studies regarding parasites of Rajiformes are needed in order to evaluate the real level of host specificity and geographical distribution of members of Acanthocotyle.

\section{Supplementary information}

Supplementary information accompanies this paper at https://doi. org/10.1186/s13071-019-3756-5.

Additional file 1: Table S1. Acanthocotyle imo n. sp. ex Amblyraja frerichsi (Krefft) (Rajiformes: Rajidae). Raw morphometric and meristic data.

Additional file 2: Table S2. Summary of morphological and morphometric characteristics of the species of Acanthocotyle considered valid.

Additional file 3: Table S3. Acanthocotyle atacamensis n. sp. ex Bathyraja peruana McEachran \& Miyake, 1984 (Rajiformes: Arhynchobatidae). Raw morphometric and meristic data.

Additional file 4: Table S4. Code for recorded species of Acanthocotyle as shown in Fig. 7. Host species, family and order plus geographical record and authority are also given.

\section{Abbreviations}

SPO: South-East Pacific; LSU rRNA: large subunit of rRNA; COX1: cytochrome $c$ oxidase subunit 1 gene; AFA: alcohol: formalin: acetic acid; PCA: principal components analysis; TL: total length; MDA: multivariate discriminant analysis; PCR: polymerase chain reaction; BI: Bayesian inference; ML: maximumlikelihood; AIC: Akaike information criterion; GTR + G: General Time Reversible model + Gamma distribution; GTR + I: General Time Reversible model + Invariant sites; MCMC: Markov chain Monte Carlo; ESS: Effective sample size.

\section{Acknowledgements}

We appreciate the support of the crew of the fishing boat "Doña Bella" and its Captain Mr. Dani Manso who kindly provided the deep-sea skates now studied. Comments, suggestions and criticisms from two anonymous reviewers strongly improved this MS

\section{Authors' contributions}

LAÑ, RE and MEO initiated the research, obtained the samples and performed the descriptions and morphological analyses. FAS played a key role in conducting the molecular analyses. All authors read and approved the final manuscript.

\section{Funding}

This study was funded by Grant FONDECYT 1140173 and Grant 5303 "Programa Semilleros de Investigación" DGI, Universidad de Antofagasta. The Millennium Institute of Oceanography (IMO), IC120019, also provided support.

\section{Availability of data and materials}

Data supporting the conclusions of this article are included within the article. The sequences generated in this study were deposited in the GenBank database under the accession numbers MH511079-MH511082 (A. atacamensis n. sp.), MH511083-MH511085 (A. imo n. sp.) (LSU rRNA gene) and MH511067MH511072 (A. atacamensis n. sp.), MH511074-MH511078 (A. imo n. sp.) (cox1 gene). Raw measurements of all specimens studied are included in Additional file 1: Table S1 and Additional file 3: Table S3. Code for recorded species of Acanthocotyle (as shown in Fig. 6) and host species, family and order plus geographical record and authority are given in Additional file 4: Table S4.

\section{Ethics approval and consent to participate}

This study was conducted under the protocol of the Ethical Commission of the Universidad de Antofagasta, Antofagasta, Chile.

\section{Consent for publication}

Not applicable.

\section{Competing interests}

The authors declare that they have no competing interests.

\section{Author details}

${ }^{1}$ Programa Doctorado Ciencias Aplicadas, Universidad de Antofagasta, Antofagasta, Chile. ${ }^{2}$ Instituto Milenio de Oceanografía, Universidad de Concepción, Concepción, Chile. ${ }^{3}$ Instituto Ciencias Naturales Alexander von Humboldt, Universidad de Antofagasta, Antofagasta, Chile. 
Received: 16 November 2018 Accepted: 21 October 2019 Published online: 30 October 2019

\section{References}

1. Klimpel S, Busch MW, Kellermanns E, Kleinertz S, Palm HW. Metazoan deep sea fish parasites. Düsseldorf: Verlang Natur \& Wissenschaft; 2009.

2. Angel MV. What is The deep sea? In: Randall DJ, Farrell AP, editors. Fish physiology series, 16. San Diego: Academic Press; 1997. p. 1-41.

3. Danovaro R, Company JB, Corinaldesi C, Onghia GD, Galil B, Gambi C, et al. Deep sea biodiversity in the Mediterranean Sea: the known, the unknown, and the unknowable. PLOS ONE. 2010;5:e11832.

4. Gambi C, Vanreusel A, Danovaro R. Biodiversity of nematode assemblages from deep-sea sediments of the Atacama Slope and Trench (South Pacific Ocean). Deep Sea Res Part I. 2003;50:103-17.

5. Sabbatini A, Morigi C, Negri A, Gooday AJ. Soft-shelled benthic foraminifera from a hadal site (7800 $\mathrm{m}$ water depth) in the Atacama Trench (SE Pacific): preliminary observations. J Micropalaeontol. 2002;21:131-5.

6. Perrone EM, Dellnnon A, Danovaro R, Croce N, Turston MH. Population biology of Hirondellea sp. nov. (Amphipoda: Gammaridae: Lysianassoidea) from the Atacama Trench (South-East Pacific Ocean). J Mar Biol Assoc UK. 2002;82:419-25

7. Nacari LA, Oliva ME. Metazoan parasites of deep-sea fishes from the South Eastern Pacific: Exploring the role of ecology and host phylogeny. Deep Sea Res Part I. 2016;115:123-30.

8. Wood CL, Byers JE, Cottingham KL, Altman I, Donahue MJ, Blakeslee AMH. Parasites alter community structure. Proc Natl Acad Sci USA. 2007;104:9335-9.

9. Salinas X, González MT, Acuña E. Metazoan parasites of the thumb grenadier Nezumia pulchella, from the south Eastern Pacific, off Chile, and their use for discrimination of host populations. J Fish Biol. 2008;73:683-91.

10. Ñacari LA, Sepulveda FA, Escribano R, Oliva ME. Acanthocotyle gurgesiella n. sp. (Monogenea: Acanthocotylidae) from the deep-sea skate Gurgesiella furvescens (Rajidae) in the South-Eastern Pacific. J Helminthol. 2018;92:223-7.

11. Kearn G, Whittington I, Chisholm L, Evans-Gowing R. A new species of Acanthocotyle Monticelli, 1888 (Platyhelminthes: Monogenea: Acanthocotylidae) from the ventral skin of the banded stingaree, Urolophus cruciatus (Lacépède, 1804), from Tasmania, Australia. Acta Parasitol. 2016;61:607-13.

12. Baylis HA, Jones El. Some records of parasitic worms from marine fishes at Plymouth. J Mar Biol Ass UK. 1933;18:627-34

13. Bush $O$, Lafferty AD, Lotz JM, Shostak AW. Parasitology meets ecology on his own terms: Margolis et al. revisited. J Parasitol. 1997;83:575-83.

14. Georgieva S, Selbach C, Faltýnková A, Soldánová M, Sures B, Skírnisson K, et al. New cryptic species of the 'revolutum' group of Echinostoma (Digenea: Echinostomatidae) revealed by molecular and morphological data. Parasit Vectors. 2013;6:64.

15. Quinn G, Keough M. Experimental design and data analysis for biologists. Cambridge: Cambridge University Press; 2002. p. 557

16. Sepúlveda FA, González MT, Oliva ME. Two new species of Encotyllabe (Monogenea: Capsalidae) based on morphometric and molecular evidence: parasites of two inshore fish species of northern Chile. J Parasitol. 2014;100:344-9.

17. Miller SA, Dykes DD, Polesky HFRN. A simple salting out procedure for extracting DNA from human nucleated cells. Nucleic Acids Res. 1998;16:1215

18. Chisholm LA, Morgan JAT, Adlard RD, Whittington ID. Phylogenetic analysis of the Monocotylidae (Monogenea) inferred from 285 rDNA sequences. Int J Parasitol. 2001;31:1537-47.

19. Littlewood DTJ, Rohde K, Clough KA. Parasite speciation within or between host species? Phylogenetic evidence from site-specific polystome monogeneans. Int J Parasitol. 1997;27:1289-97.

20. Filatov DA. Proseq: a software for preparation and evolutionary analysis of DNA sequence data sets. Mol Ecol Notes. 2002;2:621-4.
21. Larkin MA, Blackshields G, Brown NP, Chenna R, Mcgettigan PA, Mcwilliam $\mathrm{H}$, et al. Clustal W and Clustal X version 2.0. Bioinformatics. 2007;23:2947-8.

22. Posada D. jModelTest: phylogenetic model averaging. Mol Biol Evol. 2008;25:1253-6.

23. Akaike H. A new look at the statistical model identification. IEEE Trans Automat Contr. 1974;6:716-23.

24. Huelsenbeck JP, Ronquist F. MRBAYES: Bayesian inference of phylogenetic trees. Bioinformatics. 2001;17:754-5.

25. Rambaut A, Drummond A. 2007. Tracer v1.4 at http://tree.bio.ed.ac.uk/ software/tracer/.

26. Tamura K, Stecher G, Peterson D, Filipski A, Kumar S. MEGA6: Molecular Evolutionary Genetics Analysis version 6.0. Mol Biol Evol. 2013;30:2725-9.

27. Perkins EM, Donnellan SC, Bertozzi T, Chisholm LA, Whittington ID. Looks can deceive: molecular phylogeny of a family of flatworm ectoparasites (Monogenea: Capsalidae) does not reflect current morphological classification. Mol Phylogenet Evol. 2009:52:705-14.

28. Justine JL, Jovelin R, Neifar L, Mollaret I, Lim LHS, Hendrix SS, et al. Phylogenetic positions of the Bothitrematidae and Neocalceostomatidae (Monopisthocotylean monogeneans) inferred from 285 rDNA sequences. Comp Parasitol. 2002:69:20-5.

29. Price EW. North American monogenetic trematodes II The families Monocotylidae, Microbothriidae, Acanthocotylidae and Udonellidae (Capsaloidea). J Wash Acad Sci. 1938;28:109-26.

30. Goto S. Notes on some exotic species of ectoparasitic trematodes. J Coll Sci Imp Univ Tokyo. 1899;12:263-95.

31. Manter HW. Some North American fish trematodes, 10. III Biol Monogr. 1926:10:127-64.

32. Sekerak AD, Arai HP. Helminths of Sebastes alutus (Pisces: Teleostei) from the northeastern Pacific. Can J Zool. 1972;51:475-7.

33. Wierzbicka J, Piasecki W. Redescription of Pseudacanthocotyla williamsi (Price, 1938) (Monogenea) from Greenland halibut, Reinhardtius hippoglossoides (Walbaum, 1792). Acta Ichthyol Piscat. 2000;30:93-8.

34. Weigmann S. Annotated checklist of the living sharks, batoids and chimaeras (Chondrichthyes) of the world, with a focus on biogeographical diversity. J Fish Biol. 2016;88:837-1037.

35. Last PR, Weigmann S, Yang L. Changes to the nomenclature of the skates (Chondrichthyes: Rajiformes). In: Last PR, Yearsley GK, editors. Rays of the World: Supplementary Information. Clayton: CSIRO Special Publication; 2016. p. 11-34

36. Nelson JS, Grande TC, Wilson MVH. Fishes of the world. 5th ed. New Jersey: Wiley; 2016.

37. Huyse T, Volckaert FAM. Identification of a host-associated species complex using molecular and morphometric analyses, with the description of Gyrodactylus rugiensoides n sp (Gyrodactylidae, Monogenea). Int J Parasitol. 2002;32:907-19.

38. Oliva ME, Valdivia IM, Chavez RA, Molina H, Cárdenas L. Molecular and morphological evidence demonstrating two species of Helicometrina Linton, 1910 (Digenea: Opecoelidae) in northern Chile. J Parasitol. 2015:101:694-701.

39. Héritier L, Verneau O, Smith KG, Coetzer K, Du Preez LH. Demonstrating the value and importance of combining DNA barcodes and discriminant morphological characters for polystome taxonomy (Platyhelminthes, Monogenea). Parasitol Int. 2018:67:38-46.

40. Caira JN, Jensen K. A digest of elasmobranch tapeworms. J Parasitol. 2014;100:373-91.

41. Kyne PM, Simpfendorfer CA. Deepwater Chondrichthyans. In: Carrier JC, Musick JA, Heithaus MR, editors. Sharks and their relatives. II Biodiversity, adaptive physiology, and conservation. Boca Raton: CRC Press; 2010. p. 37-113.

\section{Publisher's Note}

Springer Nature remains neutral with regard to jurisdictional claims in published maps and institutional affiliations. 